Doi: $10.4274 /$ vhd. 92063

Viral Hepatitis Journal 2014; 20(2): 85-86

\title{
An Unusual Extrahepatic Manifestation of Acute Hepatitis B Infection: Epididymitis
}

\author{
Akut Hepatit B Enfeksiyonunda Sıradıșı Bir Ekstrahepatik Bulgu: Epididimit
}

\author{
Özlem ALTUNTAŞ AYDIN1, Hayat KUMBASAR KARAOSMANOĞLU1, Ahmet KEHRIBAR1, \\ Kubilay YENIGÜL2
}

${ }^{1}$ Haseki Training and Research Hospital, Infectious Diseases and Clinical Microbiology, Istanbul, Turkey

2 Haseki Training and Research Hospital, Department of Radiology, Istanbul, Turkey

\begin{abstract}
Hepatitis B virus (HBV) infection is often a mild, asymptomatic and a subclinical illness. Numerous immune-mediated extrahepatic manifestations have been described in patients with acute and chronic viral hepatitis B infection. Besides, there are only a limited number of studies on the co-existence of acute HBV infection and epididymitis in the literature. In this report, we present an adult male patient with epididymitis that might be related to acute hepatitis B. (Viral Hepatitis Journal 2014; 20(2): 85-86)

Key words: Hepatitis B, extrahepatic manifestation, epididymitis
\end{abstract}

ÖZET

Hepatit B enfeksiyonu sıkıkla asemptomatik ve subklinik seyreden bir hastalıktır. Akut ve kronik hepatit B enfeksiyonu ile birlikte çok sayıda ekstrahepatik bulgu tanımlanmaktadır. Ancak literatürde akut hepatit B enfeksiyonuna ekstrahepatik bulgu olarak epididimitin eşlik ettiği vaka sayısı sınırlıdır. Bu çalışmada, akut hepatit B enfeksiyonu ile ilişkili olduğu düşünülen bir epididimit olgusu sunulmuştur. (Viral Hepatit Dergisi 2014; 20(2): 85-86)

Anahtar Kelimeler: Hepatit B, ekstrahepatik bulgu, epididimit

\section{Introduction}

Hepatitis B virus (HBV) infection is often a mild, asymptomatic and a subclinical illness. Numerous immune-mediated extrahepatic manifestations have been described in patients with acute and chronic viral hepatitis B (1).

In up to $20 \%$ of patients, extrahepatic manifestations in acute HBV infection give signs of a serum sickness-like illness with fever, skin rash, arthralgias, and polyarthritis. These findings occur before the onset and subside with the appearance of jaundice (2). Besides, there are only a limited number of studies on the co-existence of acute HBV infection and epididymitis in the studied literature (3). In this report, we present an adult male patient with epididymitis that might be related to acute hepatitis $B$.

\section{Case}

A 28-year-old man was directed to our clinic due to elevated liver enzymes. On admission, he had a history of scrotal swelling and pain for 6 days. Physical examination was unremarkable except for left scrotal swelling and left ankle edema.

Laboratory studies showed 50-fold elevation in the liver enzymes (ALT: $2025 \mathrm{IU} / \mathrm{L}, \mathrm{AST}: 1867 \mathrm{IU} / \mathrm{L}$ ), total bilirubin: $2.5 \mathrm{mg} / \mathrm{dl}$. Prothrombine time and blood counts were normal, $\mathrm{HBsAg}, \mathrm{HBeAg}$ and anti-HBc-lgM were positive. Serological parameters of hepatitis A, C, D, cytomegalovirus, Epstein-Barr virus, mumps, VDRL, anti-HIV 1 and anti-HIV 2 were negative. Urology consultation was performed and the patient was diagnosed as having acute epididymitis by urologic examination and scrotal ultrasonography (Figure 1).

Microscopic examination and culture of urine and urethral discharge (for $C$. trachomatis, N. gonorrhoeae) were negative. Standard tube agglutination test for brucellosis, tuberculin skin test, antinuclear antibodies (ANA), anti-ds DNA were also found to be negative. Scrotal swelling, ankle edema and liver enzymes disappeared after two weeks. Furthermore, liver enzymes decreased in a month. Six months later, serological parameters were found to be HBsAg negative and AntiHBs positive. 


\section{Discussion}

Although HBV primarily affects hepatocytes, it is important to be aware of the spectrum of extrahepatic manifestations of this infection. The most commonly described extrahepatic manifestations of hepatitis B are serum sickness-like syndrome, cryoglobulinemia, arthritis, arthralgia, glomerulonephritis, polyarteritis nodosa (PAN), dermatologic manifestations (especially oral lichen planus in Turkish population), and neurologic/psychologic conditions $(1,4,5)$. The cause of these findings is generally believed to be mediated by circulating immune complexes $(2,6)$.

In the studied English literature, there are only two cases that have been reported with acute HBV infection and epididymitis as an extrahepatic manifestation. One of the cases is a 12-yearold male who was reported from Turkey (3). The other reported case was a middle-aged man from Japan, who was admitted to a hospital with acute HBV infection and epididymitis. Then he had become a carrier with complicating PAN. Interferon treatment had been given for 4 weeks and his symptoms related to PAN had alleviated (7). As in this case, HBV-associated PAN is a typical form of classic PAN and its pathogenesis has been attributed to immune-complex deposition with antigen excess (8). In our patient, both arthritis and epididymitis were found. There were no any other findings except testicular pain and HBV infection as in the American College of Rheumatology 1990 criteria for the classification of PAN. For classification purposes, a patient shall be said to have PAN if at least 3 of these 10 criteria are present (9). Our

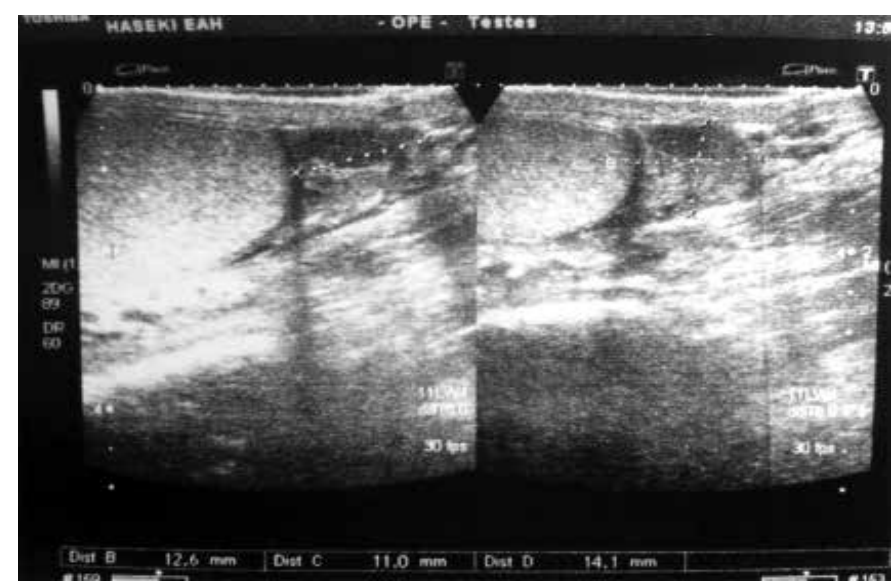

Figure 1. Marked region on the scrotal ultrasonography report shows enlarged and hypoechoic epididymis of the patient. patient's testicular pain was due to epididymitis and the symptoms disappeared spontaneously within two weeks.

Awareness and recognition of extrahepatic manifestations may be helpful for early diagnosis of HBV infection. The physician should also evaluate the patient for any extrahepatic manifestation while treating hepatitis $B$ infection.

\section{Acknowledgment}

All authors listed have contributed sufficiently to the project to be included as authors. To the best of our knowledge, no conflict of interest, financial or other, exists.

\section{Conflict of interest: None declared.}

\section{Referenses}

1. Kappus MR, Sterling RK. Extrahepatic Manifestations of acute hepatitis B virus infection. Gastroenterology Hepatology. 2013; 9(2): 123-6.

2. Koziel MJ, Thio CL. Hepatitis B Virus and Hepatitis Delta virus. In: Mandell GL, Bennett JE, Dolin R (eds.), Mandell, Douglas, and Bennett's Principles and Practice of Infectious Diseases. 7 th ed. Philadelphia: Churchill Livingstone Elsevier Inc; 2005. p. 2059-86.

3. Tasar MA, Bostanci I, Karabulut B, Dallar Y. A rare extrahepatic syndrome related to acute hepatitits type $B$ : epididymitis in an adolescent. Acta Gastroenterol Belg. 2005; 68(2): 270-1.

4. Pyrsopoulos NT, Reddy KR. Extrahepatic manifestations of chronic viral hepatitis. Curr Gastroenterol Rep. 2001; 3(1): 71-8.

5. Dogan B. Dermatological manifestations in hepatitis B surface antigen carriers in east region of Turkey. J Eur Acad Dermatol Venerol. 2005; 19: 323-5.

6. Baig S, Alamgir M. The extrahepatic manifestations of hepatitis B virus. J Coll Physicians Surg Pak. 2008; 18(7): 451-7.

7. Nakamura H, Shimizu T, Ohshiro S, Aoki H, Kaneko M, Shioda A, et al. An adult paitent with acute hepatitis type B which was protracted and complicated by polyarteritis nodosa: a case report. Hepatol Res. 2002; 24(4): 439-44.

8. Guillevin L, Mahr A, Callard P, Godmar P, Pagnoux C, Leray E, et al. French Vasculitis Study Group. Hepatitis B virus-associated polyarteritis nodosa: clinical characteristics, outcome, and impact of treatment in 115 patients. Medicine (Baltimore). 2005; 84(5): 313-22.

9. Lightfood RW Jr, Michel BA, Bloch DA, Hunder GG, Zvaifler NJ, McShane DJ, et al. The American College of Rheumatology 1990 criteria for the classification of polyarteritis nodosa. Arthritis Rheum. 1990; 33: 1088-93. 